IZA DP No. 9321

\title{
A European Perspective on Long-Term Unemployment
}

Werner Eichhorst

Franziska Neder

Verena Tobsch

Florian Wozny

September 2015 


\title{
A European Perspective on Long-Term Unemployment
}

\author{
Werner Eichhorst \\ IZA
}

\author{
Franziska Neder
}

IZA

Verena Tobsch

E-X-AKT Economic Research and INES

\section{Florian Wozny}

IZA

\section{Discussion Paper No. 9321 \\ September 2015}

IZA

\author{
P.O. Box 7240 \\ 53072 Bonn \\ Germany
}

\author{
Phone: +49-228-3894-0 \\ Fax: +49-228-3894-180 \\ E-mail: iza@iza.org
}

\begin{abstract}
Any opinions expressed here are those of the author(s) and not those of IZA. Research published in this series may include views on policy, but the institute itself takes no institutional policy positions. The IZA research network is committed to the IZA Guiding Principles of Research Integrity.

The Institute for the Study of Labor (IZA) in Bonn is a local and virtual international research center and a place of communication between science, politics and business. IZA is an independent nonprofit organization supported by Deutsche Post Foundation. The center is associated with the University of Bonn and offers a stimulating research environment through its international network, workshops and conferences, data service, project support, research visits and doctoral program. IZA engages in (i) original and internationally competitive research in all fields of labor economics, (ii) development of policy concepts, and (iii) dissemination of research results and concepts to the interested public.
\end{abstract}

IZA Discussion Papers often represent preliminary work and are circulated to encourage discussion. Citation of such a paper should account for its provisional character. A revised version may be available directly from the author. 


\section{ABSTRACT}

\section{A European Perspective on Long-Term Unemployment}

In contrast to the recently decreasing unemployment rates in the $E U$, long-term unemployment remains at alarming levels. An economic recovery will not be sufficient to get all long-term unemployed back to work; rather, there is a need for effective policies addressing the long-term unemployed. To address these issues, this paper starts with an interpretation of standard measures of long-term unemployment and alternative measures of long-term non-employment. Next, we take a closer look at active labor market policies such as training, subsidized employment and public work and investigate which kind is most effective for the reintegration of long-term unemployed persons. Subsequently, the special role of Public Employment Services (PES) and the importance of an individual approach and targeting is stressed to increase the employability of hard-to-place and distant jobseekers from the labor market. Furthermore, we take into account the role of alternative benefit systems for working-age non-employed people. In the final section, we conclude and offer policy advice with a particular focus on the EU.

JEL Classification: J64, J65, J68

Keywords: long-term unemployment, activation, Europe, disability benefits

Corresponding author:

Werner Eichhorst

IZA

P.O. Box 7240

53072 Bonn

Germany

E-mail: Eichhorst@iza.org 


\section{Conceptualising long-term unemployment}

In recent years, long-term unemployment -i.e. unemployment of more than 12 months - has been on the rise in most European Countries. In 2008, Germany and Greece both showed a 4percent level of long-term unemployment (\% of the labor force). While the share of long-term unemployed dropped to almost 2 percent in Germany, the share in Greece reached a record level of 18.6 percent in 2013. Aside from Germany, there has been a huge increase in longterm unemployment in most European countries since 2008, triggered by the crisis in 2008/2009 and the associated poor market performance and poor labor market conditions. In addition, many countries already showed structural problems as well as labor demand and supply mismatches before the crisis, which were exacerbated after the crisis. The EU average of LTU increased from 2.6 percent in 2008 to 5.1 percent in 2013 . Whereas in 2008 only five countries showed a share of LTU above 4 percent, in 2013 this already included sixteen countries. Countries like Spain, Croatia, Portugal, Ireland, Bulgaria, Italy, Cyprus, Latvia, Slovenia, Lithuania, Poland, Estonia, the UK and the Netherlands experienced alarming rises in longterm unemployment between 2008 and 2013.

Figure 1: LTU in Europe in \% of the labor force

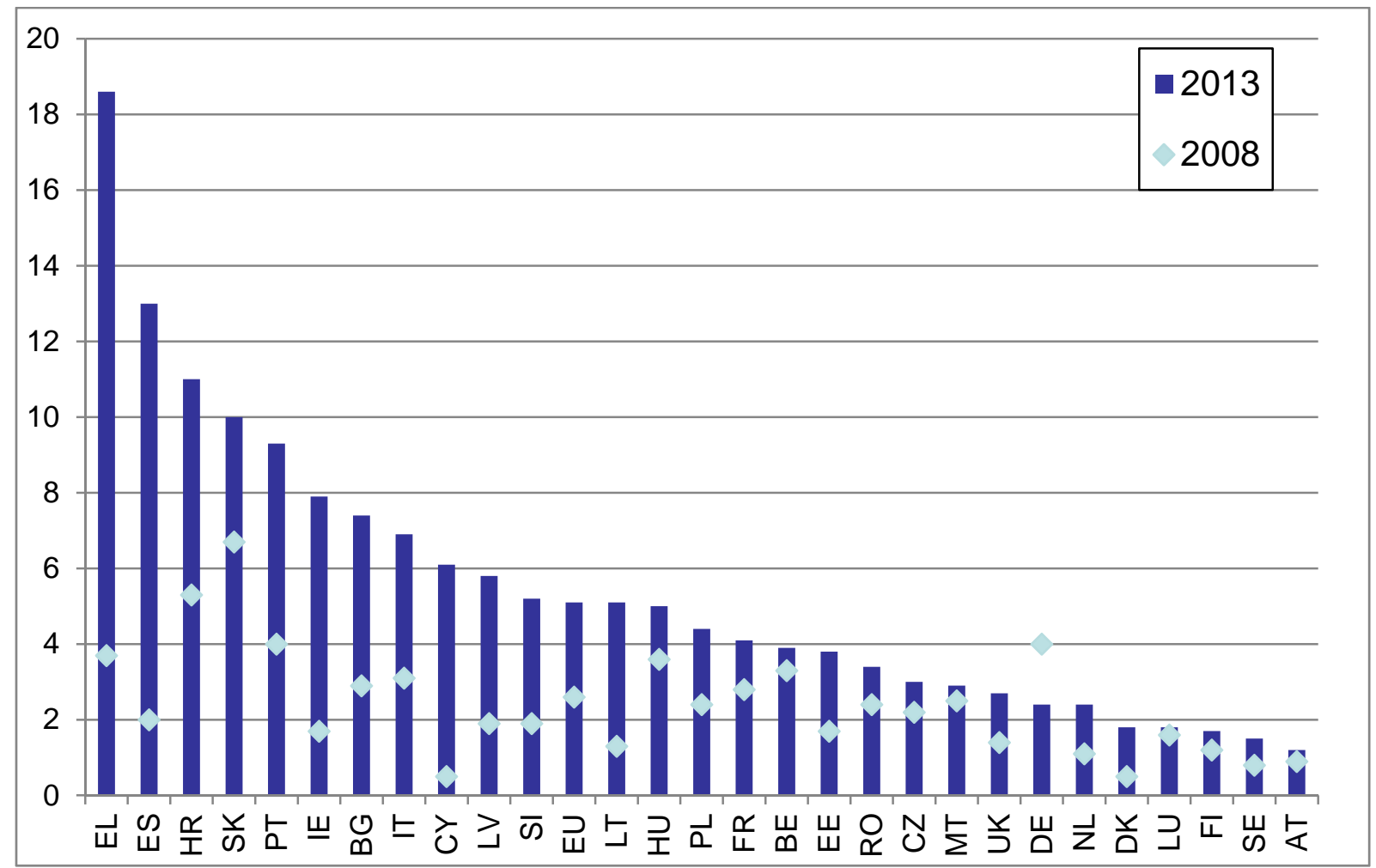

Source: European Commission ESDE Report 2014. 
Another standard figure indicates the share of LTU among total unemployment (Figure 2). However, development during and after the crisis is not so clear in this respect: half of the countries show a decrease, while the other half experienced an increase. Taking a closer look, it becomes apparent that the increases were at a higher level than the decreases. This becomes apparent when comparing the number of countries where the share of LTU was below 30 percent in 2007 (seven) and 2013 (four) and those with shares of LTU above 60 percent in 2007 (one) and 2013 (three). The shares of LTU among total unemployment increased most strongly in Ireland (+31.1 p.p.), Spain (+29.3 p.p.) and Greece (17.5 p.p.), while especially Germany, Czech Republic and Poland managed to reduce their shares. This means that in 2013, two out of three unemployed people were long-term unemployed in Greece, Slovak Republic and Ireland and every second unemployed person was a long-term unemployed in Italy, Portugal, Slovenia, Hungary or Spain. The share of LTU among total unemployment was particularly low in Denmark, Austria, Finland and Sweden. It is important to mention that increases in LTU as a percentage of total unemployment are not necessarily something negative. For instance, if a country recovers, short-term unemployed persons have a higher probability of becoming employed because they are closer to the labor market. Consequently, this mechanism increases the share of LTU among total unemployment. The opposite is also true: declining shares of LTU among total unemployment like in the Czech Republic and Poland - despite increases in LTU as a percentage of the working force (figure 1) - simply means that short-term unemployment has increased more strongly than LTU. 
Figure 2: Share of LTU in total unemployment

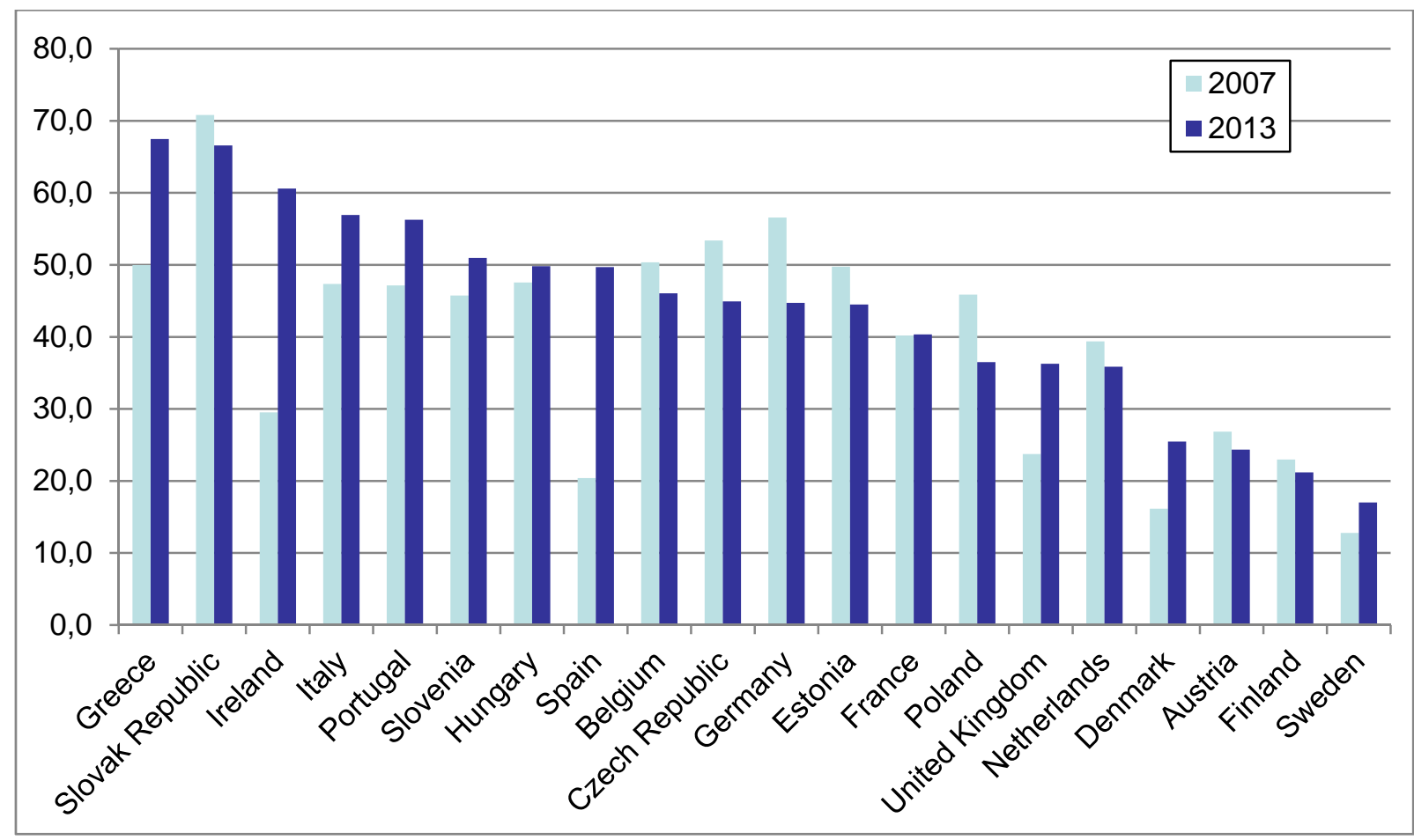

Source: OECD Employment Outlook 2014

Differentiating only between short- and long-term unemployment can be insufficient, especially in the current situation where several European countries have experienced extraordinary economic downturns. This relates to the fact that LTU already starts after 12 months of unemployment and accumulates beyond. However, the longer unemployment lasts, the worse the prospects of finding new employment become because skills and motivation decrease. Figure 3 reveals the heterogeneity between countries. For example, the decreasing LTU rates in Germany are even better understood when considering figure 3, because this decrease is mainly based upon a decrease of those who were unemployed for more than twice years. By contrast the situation in countries like Greece, Spain or Portugal is even worse because the highest increases occurred with those who were unemployed for more than two years. 
Figure 3: Unemployment/Inactivity (in percent) in selected European Countries 2003, 2009 and 2013 by duration

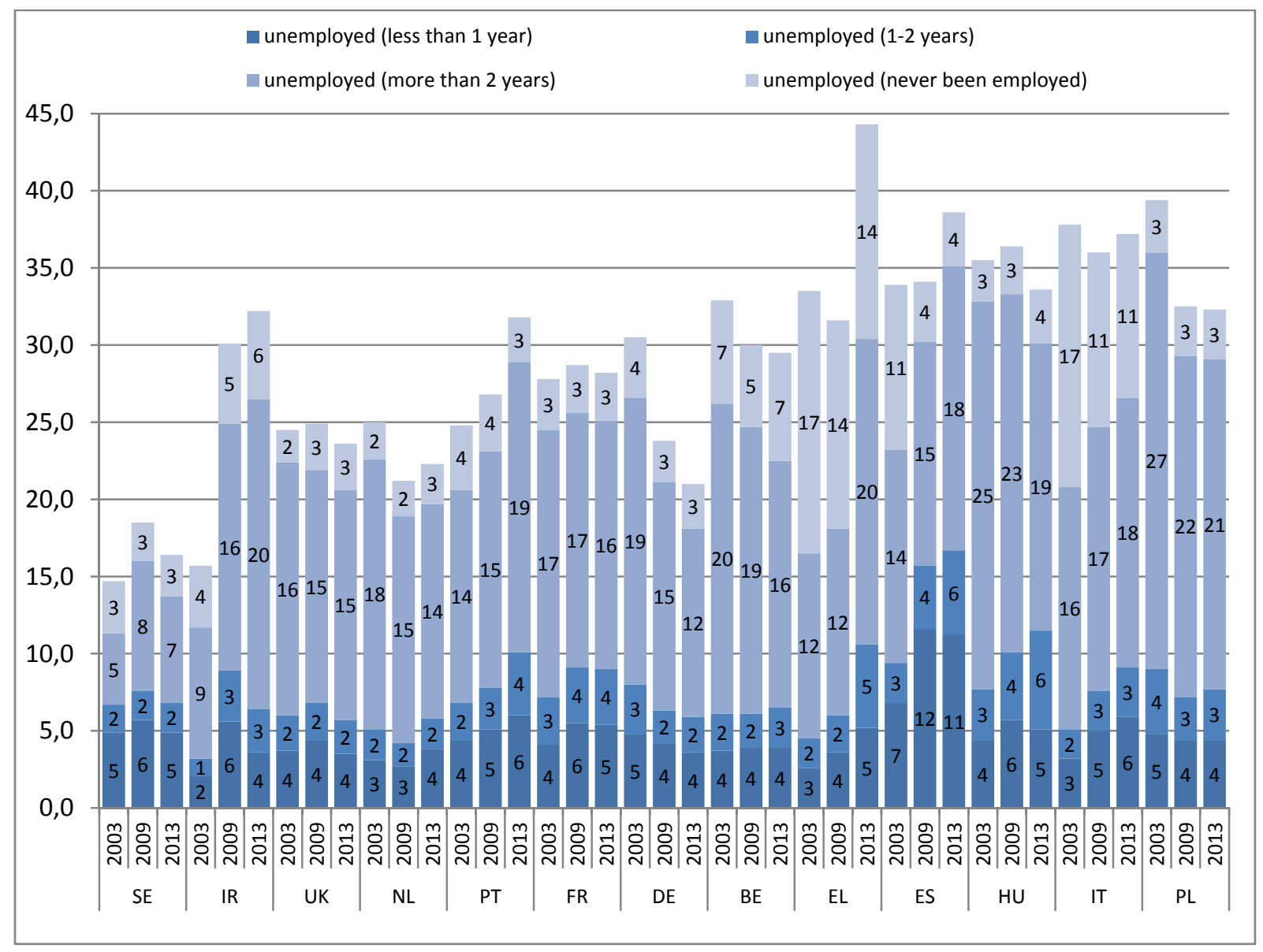

Source: EU-LFS 2003 2013, workforce aged 25 to 64 years, weighted results (own calculations).

One has to consider that standard figures do not tell the full story, given that they do not capture people receiving benefits without being classified as (long-term) unemployed. This includes inactive or discouraged people who do not participate in the labor market due to early retirement or who are permanently ill or disabled, as well as long-term participations in ALMP like subsidized employment.

This is why figure 4 shows a more comparable picture. Taking long-term unemployed and longterm inactive people together tackles the problem of classification and shows, for example, that the situation in the Netherlands is worse than in Germany, whereas figure 1 indicates no difference. Furthermore, figure 4 reveals that the situation in Italy is much worse than indicated in figure 1. However, it is important to point out that, in a cross-country comparison, higher rates of inactivity can be the result of social norms such as the male breadwinner model. Thus, having a look at the structure of the non-employed is necessary. 
Figure 4: Employment and Long-term Unemployment in Europe 2013

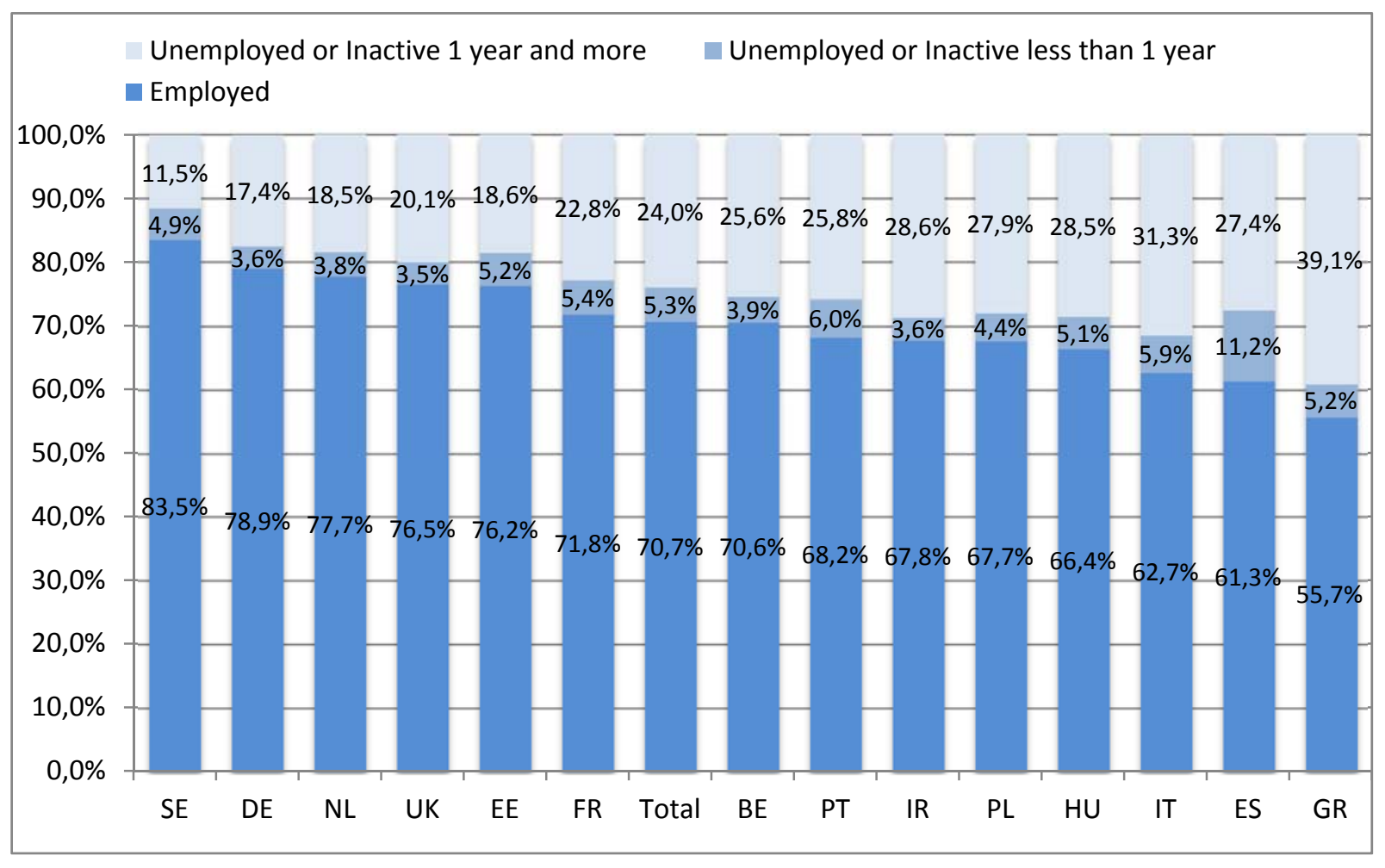

Source: EU-LFS 2013, except for France (2012), workforce aged 25 to 64 years, weighted results (own calculations).

Using EU SILC data, Figure 5 shows the shares of long-term non-employment among the total working-age population (aged 25-64 years) in six countries (Denmark, Germany, the UK, the Netherlands, Sweden and Spain). Non-employment includes all unemployed people actively seeking employment plus inactive people (out of the labor market, do not search for work) receiving disability, sickness or early retirement benefits. Long-term non-employment includes all people who had not worked for more than a year at time of the survey or who had never been employed before.

A key element explaining the relative importance of different types of long-term non-employment is the country-specific benefit system. This refers to issues such as how broad or narrow the definition of incapacity for work is and how accessible the corresponding benefits are, as well as the amount and duration of social benefits. In countries where benefit systems are non-existent or unattractive/inaccessible, the share of non-employment among working-age 
people without benefit receipt - discouraged or inactive people - is especially high. Countries like the UK, the Netherlands and Sweden had more accessible and generous disability and sickness benefit systems in the past. Despite reforms over the last decade aiming to "activate the inactive", one can still observe country-specific differences regarding non-employment and benefits systems (Konle-Seidl et al., 2014).

Against this backdrop, Figure 5 shows that the shares of long-term non-employment increased in Denmark, the UK, the Netherlands and Spain, triggered by the recession, although Sweden and especially Germany managed to reduce their shares. The increase in unemployment was most prominent in Spain, where it rose to 15 percent in 2012. While the shares of disability and sickness as well as (early) retirement benefit recipients hardly changed, the share of longterm unemployed people increased sharply from 2.5 percent in 2008 to 9.3 percent in 2012. By contrast, in 2008 Germany was the country with the highest share of LTU (3.8 percent) in this investigation but managed to reduce its share despite the crisis. 
Figure 5: Complementary measures: Long-term non-employment, 25-64 y., 2008 and 2012

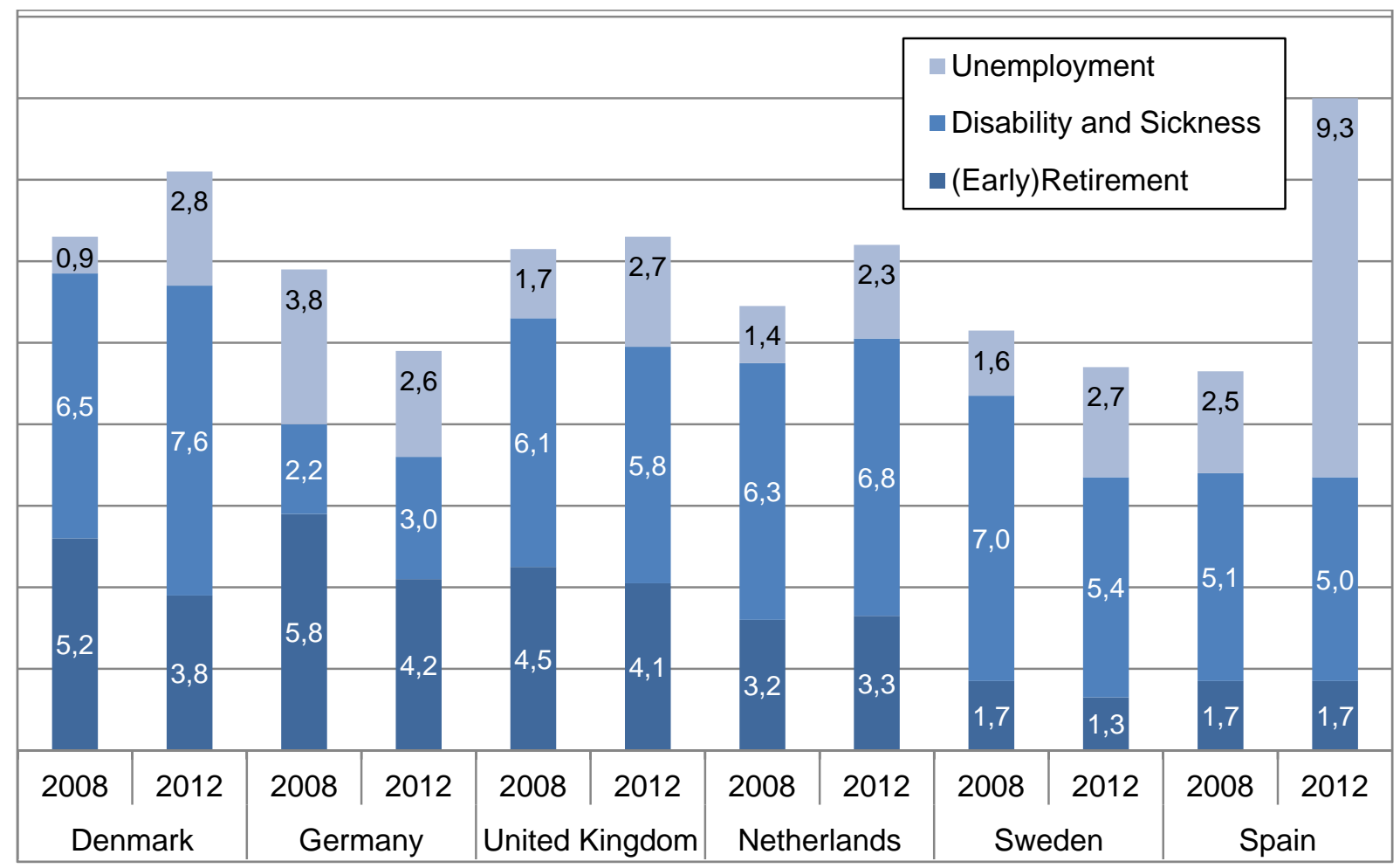

Source: EU SILC, Konle-Seidl, Rhein, Trübswetter, 2014.

As can be seen in Figure 5, the share of disability and sickness benefit recipients is not very high in Germany; indeed, despite an increase between 2008 and 2012 it remains the lowest in this investigation. The most prevalent share is that of (early) retirement beneficiaries in Germany. This decreased by 1.6 percentage points to 4.2 percent in 2012 but remains the highest share in this investigation. By contrast, in Denmark, the UK, the Netherlands and Sweden, disability and sickness are the most heavily used alternative benefit measures. Whereas Sweden and the UK managed to reduce the shares of recipients of disability and sickness benefits from 2008 to 2012, in Denmark and the Netherlands the shares continued to increase. Especially in Sweden, the share of those in early retirement is very low, due to the fact that the Swedish pension system sets only weak incentives for early retirement but more attractive and generous system for sickness benefits (Konle-Seidl et al., 2014). In 2012, the share of early retirement was at a medium level in Denmark and the Netherlands. Conversely, the share of early retirement in the UK was at a comparable level to Germany in 2012.

The economic environment plays a crucial role in explaining differences in the distribution of benefit sources. In countries that were heavily affected by the recent crisis, unemployment rates dramatically increased, which is why the share of unemployment benefit recipients for 
long-term inactive persons should increase. However, figure 6 shows that higher shares of long-term unemployed as a percentage of the active working-age population do not necessarily lead to higher shares of unemployment benefits recipients for long-term inactive persons. This is true for several country-pairs like Norway and the UK or Denmark and Belgium or Italy and Greece. On the other hand, there are several countries where the expected effect takes place, like in the Netherlands and France or Poland and Portugal. The reason for this mixed picture is that besides economic differences, variations in benefit systems and administration play an important role.

Figure 6: Long-term unemployment and the share of unemployment benefits recipients

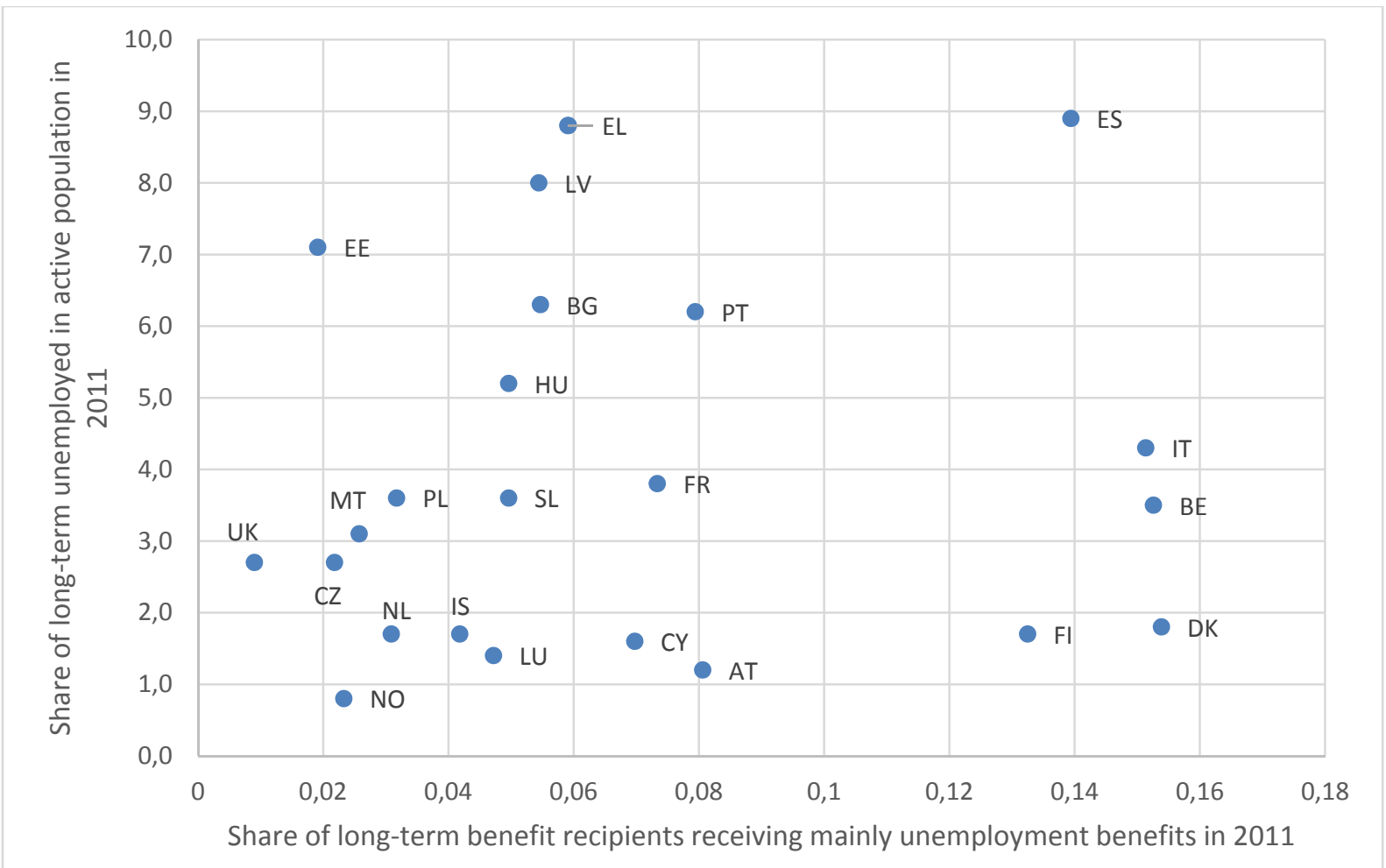

Source: EU SILC, Eurostat

Long-term inactive: Individuals between 25 and 64 who were inactive in 2010 and still at the beginning of 2011 , leading to at least 13 months of inactivity. Main source of income: Income source that generated more than 50 percent of personal income in 2011.

Differences in benefit systems lead to specific incentive structures that affect macroeconomic indicators. In the case of the LTU rate, such differences refer to the configuration of the social system. Some form of unemployment benefit receipt is common among all European countries after becoming unemployed, if specific requirements are fulfilled. However, in the case of LTU, social systems are very different, leading to specific incentive structures that might 
push long-term unemployed persons into other jurisdictions like retirement or sickness benefits and thus out of the unemployment statistics. Additionally, not being eligible or running out of entitlements without any further benefits reduces the incentives to maintain the status of unemployment. Thus, if comparing LTU between countries, it is always necessary to control for differences in the social systems.

Table 1 reveals the differences in the incentive structures for the long-term non-employed between countries, under the assumption of similar living standards such as education, health systems and occupational safety.

Table 1: Complementary measures: Long-term benefit receipt by type, 2011

\begin{tabular}{|c|c|c|c|c|c|}
\hline & $\begin{array}{c}\text { Unemploy- } \\
\text { ment } \\
\text { Benefits }\end{array}$ & $\begin{array}{l}\text { Disability/ } \\
\text { Sickness Ben- } \\
\text { efits }\end{array}$ & $\begin{array}{l}\text { (Early) Re- } \\
\text { tirement } \\
\text { Benefits }\end{array}$ & $\begin{array}{l}\text { Social Assis- } \\
\text { tance incl. } \\
\text { Housing Bene- } \\
\text { fits }\end{array}$ & $\begin{array}{c}\text { No } \\
\text { Benefits }\end{array}$ \\
\hline Denmark & 45.4 & 57.8 & - & 30.5 & 4.7 \\
\hline Germany & 27.1 & 16.1 & 19.3 & 30.3 & 16.8 \\
\hline $\begin{array}{l}\text { United King- } \\
\text { dom }\end{array}$ & 6.6 & 27.2 & 26.6 & 44.0 & 13.1 \\
\hline $\begin{array}{l}\text { The Nether- } \\
\text { lands }\end{array}$ & 5.8 & 25.7 & 34.2 & 34.3 & 17.5 \\
\hline Sweden & 17.9 & 47.1 & 34.1 & 30.6 & 7.7 \\
\hline Spain & 20.8 & 10.4 & 11.1 & 7.7 & 48.2 \\
\hline
\end{tabular}

Table 1 indicates that the Spanish social security system is not very inclusive. In 2011, 48.2 percent of all long-term non-employed people (aged 25-64 years) in Spain were without benefits. By contrast, the coverage by the social security system is significantly greater in Sweden, Denmark, the UK, Germany and the Netherlands. In Sweden, only 7.7 percent of long-term non-employed were without benefits and 4.7 percent in Denmark. Germany, the UK and the Netherlands showed slightly higher shares with 16.8 percent, 13.1 percent and 17.5 percent, respectively. In countries like Denmark, the Netherlands, the UK and Sweden, long-term nonemployed persons mainly receive disability/sickness benefits. By contrast, in Germany, disability/sickness benefits are rarely approved, because medical criteria is given a high priority and benefits are less generous compared to Scandinavian countries (Konle-Seidl et al., 2014). Table 1 shows this pattern. In Denmark, 58 percent of all long-term non employed persons received disability/sickness benefit inclusive of (early) retirement benefits in 2011. In Sweden, 
the share was 47 percent, in the UK 27.2 percent, in the Netherlands 25.7 percent and in Germany only 16.1 percent.

To conclude, although access to benefits provides income and support, ending up in early retirement or in the sickness and disability systems as an employable individual can lead to strong work disincentives. This can also be the case if there is a relatively generous benefit system for the unemployed, potentially creating unemployment traps for the long-term unemployed and the low-skilled, unless combined with effective activation policies (see Figure 7, see also Martin, 2015). In general, the success of programs depends on sufficient capacities to administer ALMPs and activation. High LTU figures are not necessarily worse than hidden unemployment or non-employment elsewhere, because at least LTUs are in principle within the reach of a potentially activating benefits system (depending on delivery of activation and ALMPs). In assessing the performance of countries, one needs to take into account the broader institutional arrangement of benefits, ALMPs, labor market regulation as well as labor demand issues/economic shocks. 
Figure 7: Net replacement rates and unemployment traps, 2013

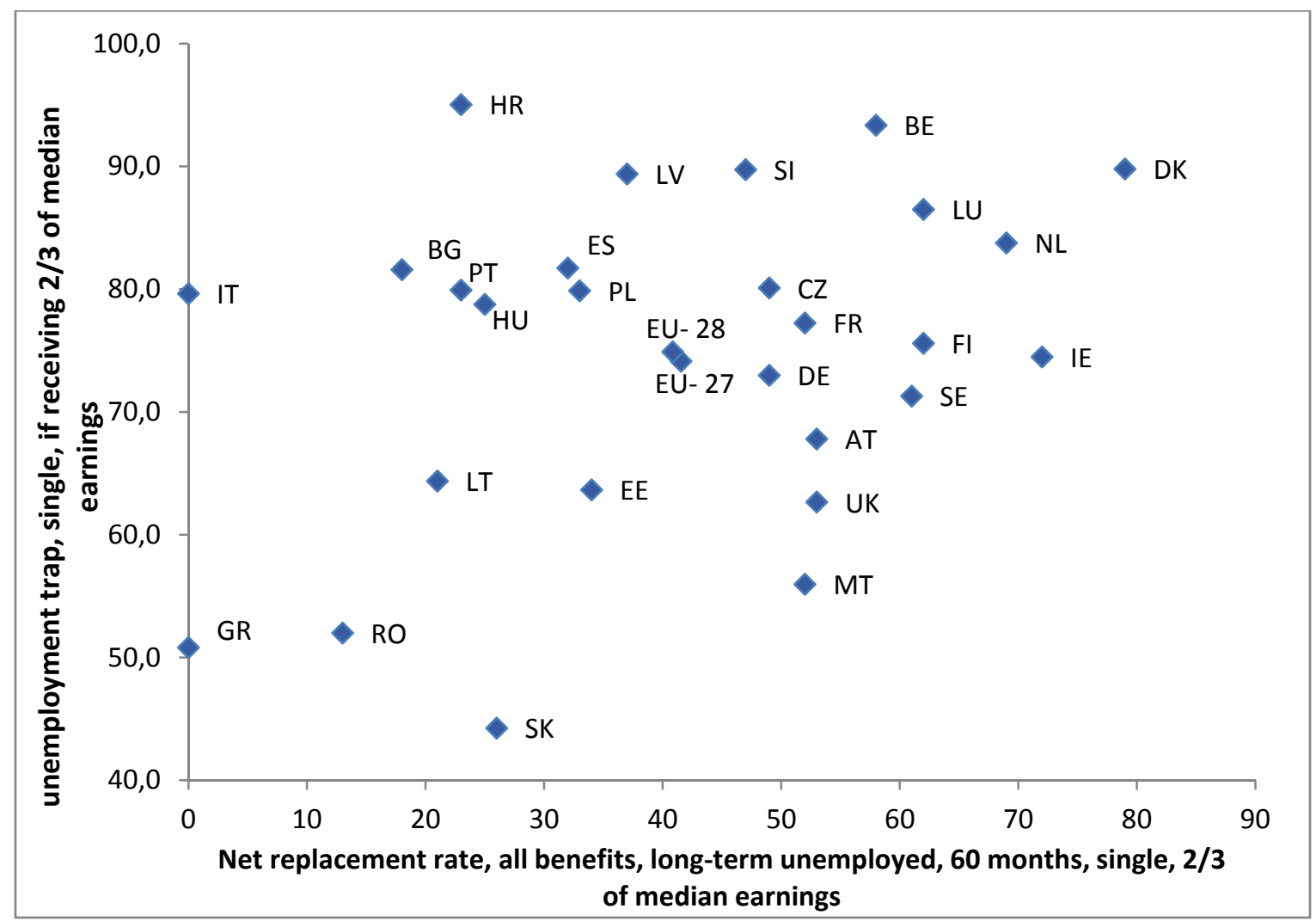

Source: European Commission ESDE Report 2014.

\section{Policy effectiveness - what do we know? Is there a set of effec- tive measures?}

In this section, we focus on policies addressing long-term unemployed and other forms of long-term benefit recipients. Which kind of intervention improves the employability, societal participation and/or labor market integration of the long-term unemployed? What do we know about the effectiveness of targeted policies and the capacities necessary to deliver them? 
Figure 8: ALMP spending and transitions

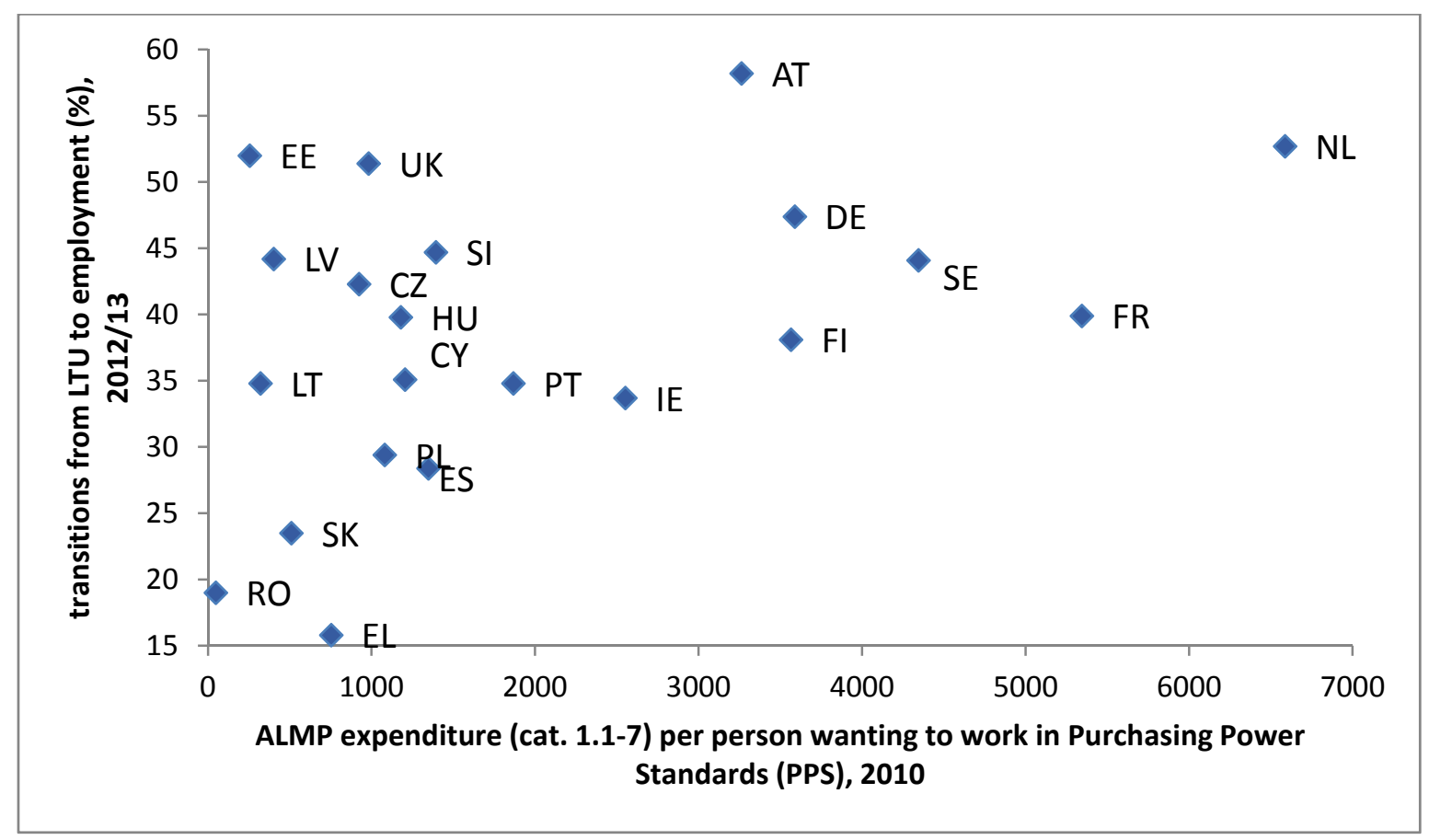

Source: European Commission ESDE Report 2014.

Figure 8 shows ALMP expenditure per person wanting to work (PPS) in 2010 and the transitions from LTU to employment in percent in 2012/2013 in most European countries. The Netherlands, France, Sweden, Finland, Germany and Austria spend a lot on ALMPs. These countries show high transitions rates from LTU to employment and were especially high in Austria (58.2 percent, highest in this investigation) and the Netherlands (52.7 percent). In comparison with the other countries, the ALMP expenditure per person wanting to work PPS of Estonia, the UK, Latvia, Slovenia, Czech Republic and Hungary do not seem particularly high. Despite this, all of these countries show quite high transitions rates from LTU to employment. The most effective country seems to be Estonia, followed by the UK, simultaneously showing very low expenditure and very high transition rates, although not taking into account the composition of the LTU population. However, one has to keep in mind that these figures do not consider the stability or quality of employment. The lowest ALMP expenditure per person wanting to work PPS and lowest transition rates in this investigation and thus the least effective spending are reported by Greece, Romania, Slovakia, Spain and Poland. It is important to point out that high ALMP expenditure is often one part of a policy alignment, which entails several other corresponding policies like lower levels of employment protection. A simple plot like figure 8 does not control for such influencing factors, which possibly leads to an overestimation of the effect 
of ALMP on transition rates. This is why we will have a closer look at the related literature in the following section.

\subsection{Active labor market policies}

The empirical evidence for the evaluation from ALMP for LTU is not significantly different from general ALMP evaluation findings. In the following, we investigate the different kinds of ALMP (training measures, hiring incentives and wage subsidies and direct job creation - public jobs) and their impacts on long-term unemployment. We highlight the aspects that must be taken into account to show some effectiveness.

In general, Card et al. (2015) find that long-term unemployed persons benefit more from ALMP interventions than other unemployed, particularly if there is emphasis on improving their human capital. Training measures tend to show positive medium- and long-run results (Card et al. 2010, 2015). Card et al. $(2010,2015)$ and Kuddo (2009) found a positive evaluation impact in the case of on-the-job training. Smaller scale schemes well-tailored to jobseekers' potential and employers' need are more effective than larger general schemes (Meager and Evans, 1998). Furthermore, training measures leading to a formal vocational qualification are also an effective way of reintegration. It is also important that training measures prepare for skills and competences demanded by (local) companies (European Employment Observatory, 2012). The Fit4Job initiative in Luxembourg is a well-targeted and labor supply oriented programme. This programme is targeted at all unemployed persons, including LTU. The scope is limited to a strong economic sector, where jobs are still available due to expansion (e.g. commerce) or growth (e.g. finance sector) and measures only accommodate a limited number of participants. Currently, four Fit4job projects - all co-financed by the ESF - are underway to include the Fit4financial markets, Fit4engineering, Fit4seniors and Fit4commerce projects (National Reform Program 2013, Luxembourg). The Fit4Job initiative brings together professionals from a particular business sector and job seekers. Through training specially developed for the sector, it aims to quickly increase job seekers' employability. Through close collaboration with professionals, it guarantees meeting the requirements of the sector and persons concerned. Concluding the Fit4Job initiative provides the flexibility of re-skilling through tailor- 
made training programmes adapted to sectoral skills demands and the evaluation of the jobseekers' competences (European Employment Observatory 2012). Emerging and pivotal new sectors such as ICT are likely to only have a moderate impact on LTU in the long run, while other sectors (logistics) - when fully developed - are more promising for the low-skilled.

Next, we consider wage subsidies and hiring incentives. Firms often receive wage subsidies or social contribution/tax reductions premiums for hiring special groups to overcome their temporarily lower productivity (Duell, 2012). Empirical results show that wage subsidies are only effective when targeted at disadvantaged groups (Bekker, 2011; Cseres-Gergely et al. 2012). If the programme is insufficiently targeted and its scale is too large, there is a high risk of deadweight losses, substitution and displacement effects (Martin and Grubb, 2001) or it only shows positive effects in the short-run (Kluve, 2006; OECD, 2005). The well-targeted START Extra programme in Hungary targeted at LTU aged 50 plus (most disadvantaged group) in 2007 until 2011 significantly increased the likelihood of finding a job for men with secondary-vocational education (Cseres-Gergely et al., 2012). Furthermore, the large-scale and long-term subsidized "Flexjobs" with specific working conditions for long-term (partially) disabled people in Denmark (Datta Gupta, Larsen and Thomsen 2015; Datta Gupta and Larsen, 2010) showed positive effects on the employability for the target group (+33 pp). However, the programme did not reach the most disadvantaged and had issues with cost effectiveness and deadweight losses, as substitution and displacement effects. The success of a wage subsidies programme also depends on the extent to which it is combined with other measures (targeting, follow-up) to minimize deadweight and substitution effects (Liebig, 2009; Duell and Vogler-Ludwig, 2011).

In general, direct job creation is less successful than other types of ALMPs (Kluve and Schmidt, 2002; Kluve, 2010; Card et al. 2010, 2015; Duell, 2012). It is often associated with problematic lock-in effects and side-effects on other forms of employment. Like subsidized wage programmes, the success of direct job creation programmes is increased by being small scale and effectively targeting disadvantaged groups. As an example, the Pathways to Work programme - a major public employment programme in Hungary during 2009 and 2010 - was unable to change employment changes despite reaching its target group (Köllö and Scharle, 2011). According to Köllő and Scharle (2012) and Mýtna Kurekova et al. (2013), public work programmes are admittedly unable to reduce long-term unemployment but can provide temporary relief to jobless households and may also help to reduce social tensions at the local level. Therefore, 
they can stabilize and motivate disadvantaged groups and guarantee that these people do not completely lose contact with the labor market. However, when used on a large scale, they are not only ineffective but may even aggravate the problem (Harvan, 2011). When well designed and combined with some training, public jobs show some effectiveness. Experiences with social enterprises have shown positive results for hard-to-place jobseekers (Duell, 2012).

\subsection{The specific role of the public employment service}

Given the evidence, there is no priory preference for a certain type of ALMP programme. In recent years, the importance of the individuality of services in working with hard-to-place jobseekers has become apparent. The overall aim is to identify those at risk of becoming longterm unemployed, as well as preventing LTU from occurring in the first place. Using profiling systems, counsellors identify those at risk of LTU as early as possible and segment customer into categories of support. For example, in France, Portugal and Austria, the PES segments jobseekers into three groups from the more to less employable, whereas in Poland, Germany and Estonia there is a distinction between standard support and case management for hardto-place unemployed persons. Being classified as less employable, these jobseekers receive intensified guidance and support to eliminate any obstacles. Key elements for a successful PES include the early identification and better targeting of measures via individual action plans (OECD LEED, 2013; European Commission, 2014). The quality of an employment-oriented case management depends on factors such as the availability of a distinct personal counsellor or changing counsellor, the caseload of the counsellor, the frequency of meetings (which, in practice, depends on the needs of each customer and/or the capacity and workload of their counsellors), the individuality of support, viable individual action plans, the role of monitoring and/or counselling, access to integrated approaches - given that institutional cooperation is important for people who face multiple employment barriers - as well as the objective of sustainability of jobs vs. early exit from benefits.

As a first step, profiling using statistical methods are generally applied, followed by case management using the counsellor's skills and experiences to facilitate individualized support. The 
more distant a jobseeker is from the labor market, the more $\mathrm{s} /$ he can benefit from individualized approaches in combination with additional measures such as follow-ups and a reasonable caseload for PES counsellors. Intensified support tailored to an individual's need - including frequent counselling sessions with the same counsellor - brings positive results.

Various profiling tools have been developed in many countries to make labor market integration more effective by better targeting services and scarce resources. All profiling methods aim to identify the strengths and weakness of the individual, identifying those with the highest risk of becoming LTU or unemployed and thus the level of assistance they need to be (re-)integrated, whereby they can develop an individual action plan most suitable to the personal requirements. To identify the role of profiling systems in achieving the effective labor market integration of job seekers, a conference was held under the European Commission's new mutual learning programme for PES, whereby Weber (2011) summarized the results. The empirical results of profiling methods are very mixed, because in recent years many different profiling methods in different countries have been developed independently, with different degrees of success. To show some effectiveness, the methodology and underlying data sources of a profiling tool need to be very reliable; otherwise, a trained and qualified counsellor also provides unsuitable advice. To conclude, there are some lessons for the future to develop and implement more effective and reliable profiling methods.

Approaches to profiling should progress towards more holistic profiling methods, moving away from simply gathering information about a jobseeker's work experience and formal qualification to information on his/her generic and soft skills. Lessons regarding the alignment between labor market policy design and implementation rules must be drawn and shared. Regulations governing access to different PES services - including ALMP - need to be sufficiently flexible to allow for profiling outcomes having an impact on resource allocation. Furthermore, the right balance needs to be found between man and machine in profiling and determining resulting resource allocation. Counsellors should be involved in the development (planning, design and piloting) of (statistical) profiling systems and decision-making concerning resource allocation. Better training is also needed to increase buy-in and optimize the outcomes of profiling tools (particularly to obtain reliable information on generic and soft skills). Finally, there is a need for longer-term testing and evaluation to determine the costs, benefits and reliability of profiling tools. 
As seen before, the caseload of a counsellor is a decisive factor for the individuality of an action plan and thus better reintegration prospects into the labor market. Table 2 provides an overview of the caseload in different European countries, based upon the analysis of information provided by 30 PES through a questionnaire completed between February and May 2014 (Manoudi et al., 2014). In Slovakia, the caseload was the highest in this investigation with 928 clients per year for one counsellor, while it was the lowest in Germany and with 135 clients. In Belgium-Le Forem and Sweden, counsellors dealt with a slightly higher number of client per year (170-180). While Finland, Italy, Poland and Estonia showed relatively low average caseloads (210-250), the caseloads in France, the Czech Republic, Lithuania and Malta were on an upper average level (350-390). The counsellors' caseloads were especially high in Belgium-Actiris, Greece, Croatia, Ireland and Portugal (exceeding 500).

\section{Table 2: Caseload (clients per year), 2014}

\begin{tabular}{|l|c|c|}
\hline Country & \multicolumn{1}{|c|}{ Caseload } & \multicolumn{1}{|c|}{ Specialist counsellors } \\
\hline Germany & 135 & 75 \\
\hline Belgium-Le Forem, Sweden & $170-180$ & \\
\hline Finland, Italy, Poland, Estonia & $210-250$ & Finland (114), Estonia (100- \\
\hline $\begin{array}{l}\text { Czech Republic, France, Lithuania, Malta } \\
\text { Belgium-Actiris, Greece, Croatia, Ireland, Por- } \\
\text { tugal }\end{array}$ & $350-390$ & France (70), Malta (214) \\
\hline Slovakia & $>500$ & \\
\hline
\end{tabular}

Data Source: Manoudi et al. 2014

Some countries have special counsellors dealing with jobseekers who are more distant to the labor market and thus less employable (including LTU as well as other groups). Their caseload is smaller than 'generalist' counsellors' (European Commission, 2014). For example, in France, counsellors supporting the most distant people from the labor market (including LTU) support only 70 jobseekers, while generalists have a caseload of 135 clients. In Germany, an employment-oriented case manager (receiving special training) supports only 75 unemployed with multiple employment barriers and decides which measures are best suited for each person. Poland and Croatia are planning to introduce similar approaches. Belgium, Latvia, Portugal and Slovakia do not distinguish between counsellors dealing with long-term unemployed and 
other groups. This means that counsellors have the same caseload regardless of the proportion of LTU among their clients (European Commission, 2014).

Many studies show that a lower caseload results in more intensive and better counselling and better job placement (Kruppe et al., 2008; Hofmann et al., 2010; Fertig, 2015), extending beyond the 'standard' activation setting implemented in Germany since the mid-2000s (Eichhorst et al., 2008; Spermann, 2015). In the "Berliner Job Offensive" project, 600 additional job counsellors were provided in Berlin's job centers to guarantee more individualized and intensified support. Fertig (2015) found that individual employment probability could be increased by 10 percentage points combined with a more stable employment experience, as well as the termination of benefit receipts and a lower reliance on ALMP programmes. These positive effects could be investigated on unemployed both closer and more distant to the labor market. The establishment of a direct, lasting and trustful relationship between PES and clients is seen as crucial.

Rosholm (2014) highlights the role of meetings with case workers. Traditional activation shows only limited effects, especially when considering their high costs, lock-in effects and inflexibility. Conversely, PES counselling is a simple, cost-effective, flexible and individual instrument that can improve and intensify the job search activities of (employable) unemployed persons but cannot stand alone for the most disadvantaged. Regular meetings with a case worker can vary in frequency, content and character, depending on the specific competences of the case workers. Priorities at the interview(s) can vary and can be adjusted; see, for example, job search assistance, reality check, moral support, selection of suitable ALMP, agreement on action plan, monitoring, etc. A more frequent meeting approach is easy to implement and easily adaptable to cyclical changes. Furthermore, using randomized experiments, the evaluation of their implementation or intensification is quite easy. Many studies show positive effects on transition to work after as well as even before the interview and hence a simultaneous reduction in unemployment and the costs of ALMPs. See, in particular, the experiments with different sequences of interviews in Denmark: QBW1 and QBW2 (Graversen and Ours, 2008, Rosholm, 2008). The Quickly Back to Work programme in 2005 and 2006 comprised early and intensive job search assistance. After one month of unemployment, weekly or twice-monthly meetings were held and after four months additionally early activation was arranged, whereby job finding rates were increased by 20-30 percent. In 2008, the QBW2 arranging twice- 
monthly meetings increased the subsequent employment rate by 10 percent over the next two years compared with the control group, which attended meetings only every 13 weeks. Rosholm highlights the shift from traditional activation towards a case worker approach. However, increasing the frequency of meetings does not necessarily help the least employable workers (it can increase the transition rate into disability benefits) unless it is complemented by other supportive measures. This is also in line with the limited effectiveness of "work first" policies mainly relying on sanctions when addressing the long-term unemployed. This might lead to quick exits from benefits but not to sustainable employment, thereby creating a high risk of job loss later on (see also Card et al. 2015, and Martin, 2015, with reference to the Swiss experience).

The UK also has vast experience with activation programs for the unemployed (Martin, 2015). The New Deal programs introduced in the late-1990s provided for up to four months - a period known as the Gateway - for intensive, personalized help and support to find an unsubsidized job. This improved the jobseeker's availability, as well as the involvement of private employers (Martyn, 2007) and showed positive impacts on the motivation of participants. The Employment Retention and Advancement (ERA) - launched in 2003 - aimed at improving job retention and advancement for low-wage workers, including long-term unemployed, with preand post-employment assistance, work-related services and financial incentives through three main program stages: the 'Gateway', the 'Intensive Activity Period' (IAP) and 'Follow Through'. ERA helped long-term unemployed persons to find jobs more quickly and remain at their initial jobs longer than in the control group. The results regarding the LTU are the most significant when compared to the other subgroups. The Work Programme - introduced in 2011 - also targeted long-term unemployed persons by providing tailored support delivered largely through the private and voluntary sectors, support for two years resulting in sustainable work, delivered through a network of prime contractors and subcontractors, operating under a payment-by-results regime based upon increased freedom to develop provision for the supported individuals. The performance of the Work Programme is at similar levels to previous programmes, although it struggles to improve outcomes for harder-to-help groups (National Audit Office, 2014). The most recent Help to Work initiative supports the hardest-to-help to get off benefits and into work with tailored back-to-work plans for individuals, intensive coaching, meeting with a Jobcentre Plus adviser every day or taking part in a community work placement for up to six months, with potential sanctions including the loss of benefits for a certain period. 


\subsection{Sickness and disability insurance}

When requirements of unemployment benefits are high (stricter activation) and alternative benefit systems such as disability and sickness or early retirement are easy to access and generous, this typically leads to some outflows. As seen in the first chapter, this is especially pronounced in Sweden, Denmark, the UK and the Netherlands. Petrongolo (2009) found evidence for the interaction between alternative benefit systems - and particularly invalidity benefits resulting from the introduction of the Jobseekers' Allowance (JSA) in the UK in 1996 (Martin, 2015). One of the most important changes was a substantial tightening of search requirement for eligibility and the related administrative hurdle. Consequently, the inflow in JSA decreased sharply in the month following the reform and those unemployed were 2.5-3 percent more likely to move from unemployment into incapacity benefit spells. Further proof was found by Lammers et al. (2012) in the Netherlands. Before the reform, unemployed people turning 57.5 years were allowed to stop all search activity, whereas after a reform in 2005, elderly people were also required to formally report their job search efforts to the employment office to avoid a (temporary) cut in benefits. While the change in the strictness in search requirement significantly increased their transition into employment $(+6 / 11 \%$ male/female), the flow to disability insurance schemes also increased (+4/9\% male/female).

To avoid this outflow in alternative benefit systems, a reform in unemployment benefits must be combined with monitoring as well as tighter eligibility criteria in sickness and disability schemes: see - for example - the development in the Netherlands (Koning and Lindeboom, 2015) Until the mid-2000s, disability benefits were strongly used to shed labor "smoothly", as an alternative to more costly firings and less generous/more demanding unemployment benefits; indeed, ca. 25-50\% of inflow into disability was hidden unemployment. A stepwise policy reversal took place to prevent this hidden unemployment. Firstly, the incentive of employers to move workers into disability was reduced by making them responsible for sickness pay for up to two years and via experience rating regarding disability benefits for up to ten years. Second, the gatekeeping was increased with a protocol establishing employer and worker requirements regarding a return-to-work plan at the beginning of the sickness period. The third 
measure was the tightening disability eligibility criteria combined with a wage supplement for working partially disabled people. These policy changes become apparent in the respective figures, given that the different set of incentives significantly changed the employers' behaviour and resulted in a massive decline in reliance on disability benefits and related expenditure. However, there were still two side-effects, namely a tendency to use (cheaper) fixedterm contracts and some disabled persons being left without benefits. A similar expansion of activation to disability benefit systems can be observed in the UK (Martin, 2015).

\section{Policy conclusions}

Our analysis shows that combatting long-term unemployment in Europe has broader implications, also referring to labor demand issues and general questions about labor market reforms, making employment systems more inclusive, including with respect to those entering the labor market after longer periods of non-employment. Employment protection, minimum wages and educational system play a role here.

In terms of targeted activation policies, activation (only) for LTU is certainly too late; rather, the intensity of activation should be maintained over a longer period - if needed - and adapted to individual difficulties. This calls for effective profiling as well as sufficient capacities in the public employment service. We can see from the available evidence that regular meetings/interviews and individual action plans establishing an individualized integration pathway can make a difference, although they require the use of suitable, targeted activation measures. Given the evidence, there is no priory preference for a certain type of ALMP program; however, training elements are crucial in improving the employability of long-term unemployed people and show positive medium- and long-term results. While targeting and tailoring are important, efforts to stabilize employment are crucial, particularly via adding a training component to ALMP programs.

Comparative work and studies on the interaction between different benefit systems also show that prevent long-term inactivity on benefits, activation policies need to be introduced systematically in benefit systems other than unemployment (e.g. disability and sickness). 
What can the EU do in this context, when the effective delivery of activation policies is mostly an issue for national policy-makers and decentralized PES? First, policy effectiveness can certainly benefit from the support for policy innovation and experimentation available via the European Social Fund and peer review procedures, stimulating mutual learning and policy improvements. Second, it would make sense to have an (early) activation guarantee combined with a proper assessment at the beginning of unemployment via (regular) interviewing and systematic follow-up, with a strong emphasis on counselling and identifying individual barriers to employment. However, this implies support for capacity building, particularly in those EU member states that have seen the most significant increase in LTU over recent years and cannot provide sufficiently intensive and individualized services. Funds and training for PES are important to ensure an appropriate number of skilled case workers, thereby limiting their case load and increasing the quality and frequency of interviews and related supportive measures. 


\section{References}

Arpaia, A, A. Kiss, B. Palvolgyi, and A. Turrini (2014), "Labour mobility and labour market adjustment in the EU", Economic Papers 539, European Economy, European Commission, directorate General for Economic and Financial Affairs.

Autor, D., Duggan, M. (2003): The rise in the disability rolls and the decline in unemployment. Quarterly Journal of Economics 118, 157-205.

Autor, D., Duggan, M. (2006): The growth in the Social Security disability rolls: a fiscal crisis unfolding. Journal of Economic Perspectives 20, 71-96.

Card, D., Kluve, J.; Weber, A. (2010): 'Active Labour Market Policy Evaluations: A Meta-Analysis', The Economic Journal No. 120, Issue 546, 452-477.

Card, D.; Kluve, J.; Weber, A. (2015): What Works? A Meta Analysis of Recent Active Labor Market Program Evaluations. IZA Discussion Paper 9236.

Datta Gupta, N.; Larsen, M. (2010): Evaluating Labour Market Effects of Wage Subsidies for the Disabled - the Danish Flexjob Scheme, SFI Working Paper 07/2010.

Datta Gupta, N.; Larsen, M.; Thomsen, L.S. (2015): Do wage subsidies for disabled workers reduce their non-employment? Evidence from the Danish Flexjob scheme. IZA Journal of Labor Policy 4:10.

Duell, N.; Vogler-Ludwig, K. (2011): The role of Public Employment Services in Youth Integration. A review of Good Practice, Analytical Paper, Pes to Pes dialogue, The European Commission Mutual Learning Programme for Public Employment Services, DG Employment, Social Affairs and Inclusion, April, 2011.

Duell, N. (2012): Can active labour market programmes reduce long-term unemployment?, Thematic Review Seminar on "Tackling Long-Term unemployment - effective strategies and tools to address long-term unemployment", Brussels, 8 November 2012, Mutual Learning Programme, Autumn Seminar 2012

Eichhorst, W.; Grienberger-Zingerle, M.; Konle-Seidl, R. (2008): Activation Policies in Germany: From Status Protection to Basic Income Support, in: W. Eichhorst, O. Kaufmann and R. KonleSeidl (eds.), Bringing the Jobless into Work? Berlin: Springer 2008. (http://www.iza.org/en/webcontent/publications/papers/viewAbstract?dp_id=2514)

European Commission (2015): Labour Market and Wage Developments in Europe.

Fertig, M. (2015): Quantitative Wirkungsanalysen zur „Berliner Joboffensive“, mimeo, Köln. 
Graversen, B. K.; van Ours, J.C. (2008): "How to help unemployed find jobs quickly: Experimental evidence from a mandatory activation program." Journal of Public Economics, 92 (2008), 2020- 2035.

Hofmann, B.; Krug, G.; Kruppe, T.; Kupka, P.; Osiander, C.; Stephan, G.; Stops, M.; Wolff, J. (2014): Beratung und Vermittlung von Arbeitslosen. Ein Literaturüberblick zu Ausgestaltung und Wirkung. In: Sozialer Fortschritt, Jg. 63, H. 11, 276-285.

Hofmann, B.; Krug, G.; Sowa, F.; Theuer, S.; Wolf, K. (2010): Modellprojekt in den Arbeitsagenturen: Kürzere Arbeitslosigkeit durch mehr Vermittler. IAB-Kurzbericht Nr. 9.

Kluve, J. (2010): The Effectiveness of European Active Labor Market Programs. Labour Economics 16 (6), 904-918.

Kluve, J. (2006): The Effectiveness of European Active Labour Market Policy, IZA Discussion Paper No. 2018, Bonn, 2006.

Kluve, J.; Schmidt, C.M. (2002): Can Training and Employment Subsidies Combat European Unemployment?. Economic Policy 35 (17), 411-448.

Koning, P.; Lindeboom, M. (2015): "The Rise and Fall of Disability Insurance Enrollment in the Netherlands." Journal of Economic Perspectives, 29(2), 151-72.

Konle-Seidl, R. (2011): Profiling systems for effective labour market integration. Use of profiling for resource allocation, action planning and matching, Pes to Pes dialogue, The European Commission Mutual Learning Programme for Public Employment Services, DG Employment, Social Affairs and Inclusion, May, 2011.

Konle-Seidl, R.; Rhein, T.; Trübswetter, P. (2014): Erwerbslose und Inaktive in verschiedenen Sozialsystemen. IAB Kurzbericht 8/2014.

Kruppe, T.; Schiel, S.; Schröder, H.; Gilberg, R. (2008): Mehr Vermittlungen durch mehr Vermittler? Ergebnisse des Modellversuchs "Förderung der Arbeitsaufnahme" (FAIR). IAB-Bibliothek 312, Bielefeld: Bertelsmann.

Kuddo, A. (2009): Employment Services and Active Labor Market Programmes in Eastern European and Central Asian Countries, World Bank. World Bank SP Discussion Paper No. 0918, Washington DC, 2009.

Lammers, M., Bloemen, H., and Hochguertel, S. (2013): Job search requirements for older unemployed: Transitions to employment, early retirement and disability benefits. European Economic Review 58, 31-57.

Manoudi, A.; Nevala-Hall, A. M.; Scharle, A.; Csillag, M.; Metcalfe, H.; Duchemin, C.; Maillart, I. (2014): Small Scale Study on PES Business Models, European Commission, June 2014. 
Martin, J.P. (2015): Activation and active labour market policies in OECD countries: stylised facts and evidence on their effectiveness. IZA Journal of Labor Policy 2015, 4:4.

Martyn, T. (2007). Training for work is more effective than Working for the Dole. Uniya.

National Audit Office (2014): The Work Programme.

Petrongolo, B. (2009): The long-term effects of job search requirements: Evidence from the UK JSA reform, Journal of Public Economics (93), 1234-1253

Rosholm, M. (2014): Do case workers help the unemployed? IZA World of Labor 2014: 72.

Rosholm, M. (2008): Experimental Evidence on the Nature of the Danish Employment Miracle. IZA Discussion Paper No. 3620.

Spermann, A. (2015): How to fight long-term unemployment: lessons from Germany. IZA Journal of Labor Policy 4 (1), 1-15. (https://scholar.google.com/citations?view_op=view_citation\&hl=en\&user=LFPNbBsAAAAJ\&sortby=pubdate\&citation_for_view=LFPNbBsAAAAJ: sSrBHYA8nusC)

Weber, T. (2011): Profiling systems for effective labour market integration. Thematic synthesis. 